\title{
Achievement of the Ancient Hindu way of Propagation of Education and suggestion of incorporation of some of the methods in the teaching of the modern Medical Education in India: Look back to go forward
}

\author{
N Ganguly N. ${ }^{{ }^{*}}$ \\ DOI: https://doi.org/10.17511/ijmrr.2020.i02.11
}

1* Narendra N Ganguly, Associate Professor, Department of Surgery, Jorhat Medical College and Hospital, Jorhat, Assam, India.

The great Author F. Max Muller said that if written scripts were not invented the Indian scholars would have retained the treasure house of the knowledge of the Hindus in their memory even today with the same efficiency as of today's written world of knowledge. The question appears here is what went wrong? Why the students cannot be taught how to learn a vast amount of literature as efficiently as the Hindus did for 9 millennia and more.Medical science is progressing in a quick stride. The amount of research materials being updated daily is very high. Expectations of patients and their attendants are also increasing day by day. The modern-day treating Doctors need to be aware of more things today than a hundred years back. The studies show that many patients may suffer from death or complications if their treating Doctors are not learned enough. It cannot be overemphasized that a learned Healer is way better than one who is half learned. The present-day experimentation with the teaching methods of the medical subjects needs to be revisited, at least in India. The experimentation of teaching the teachers in newer teaching methods and the introduction of the ATCOM module may or may not bear fruit. The involvement of non-treating faculties in imparting crucial parts of teaching like attitudes and communications in the hospital high tension areas will not be successful. Just the way a great Chef cannot train a Sniper, the same way this will surely fail. The proper person at a proper teaching position should be followed. A short advanced course in Medical Education, A short Fellowship or publication of few papers on education will not convert a Nontreating faculty equivalent to the faculty of Surgery. Theoretically, it sounds good,but in reality, it probably won't work. The students would bein confusion.

Keywords: Medical education, India, Hindu

\section{Corresponding Author}

Narendra N Ganguly, Associate Professor, Department of Surgery, Jorhat Medical College and Hospital, Jorhat, Assam, India. Email: drganguly@yahoo.com

\section{How to Cite this Article}

Ganguly NN. Achievement of the Ancient Hindu way of Propagation of Education and suggestion of incorporation of some of the methods in the teaching of the modern Medical Education in India: Look back to go forward. Int J Med Res Rev. 2020;8(2):207212.

Available From

https://ijmrr.medresearch.in/index.php/ijmrr/article/ view/1164
To Browse

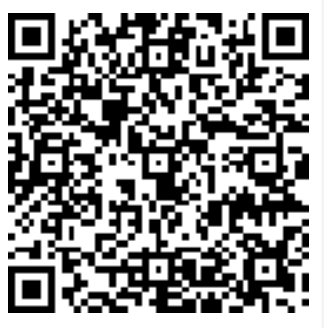

Manuscript Received 2020-02-24

Conflict of Interest No
Review Round 1 2020-03-07

Funding Nil
Review Round 2 2020-03-12

Ethical Approval Yes
Review Round 3

Plagiarism X-checker $9 \%$
Accepted 2020-03-17

Note

(C) 2020 by Narendra N Ganguly and Published by Siddharth Health Research and Social Welfare Society. This is an Open Access article licensed under a Creative Commons Attribution 4.0 International License https://creativecommons.org/licenses/by/4.0/ unported [CC BY 4.0].

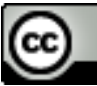




\section{Introduction}

Much experimentation is going on in the system of modern medical education in India. The introduction of sub-specialties has opened up more challenges and debates. The original thought of improvement of medical care on the introduction of the courses hascreated problems and complicacy. Not only the "treatment as a whole" principle suffered, the complexity of knowing about "more and more of less and less" failed to deliver the desired goal of improved medical care in India. The now-disbanded Medical Council of India is to blame on the mess. Ideas without vision have ruined the medical education system. It was a welcome step that the MCI is replaced with NMC now. However, it seems that in the disguise, the same degenerate ideas are running the show. It can't be denied that Indian Doctors continue to shine the world over. These doctors shine on their own merits. The system has very little to offer for their success. At this juncture, a holistic approach to the teaching methods of modern medical science needs to be followed. To be able to successfully treat the ill person as a whole by a lead healer should be an ideal situation.

Sending referral has become the norm. As a result, nobody cares and very few are cured of a serious problem. The COVID 19 Pandemic has exposed the situation well. We are now depending on the MBBS Passed professionals as well as the Final year students for treating the population in such a dreadful condition. The importance of specialists now has proven the benefits of a step ladder approach in medical education and health care. Severely inefficient and insufficient super specialists are now in self-quarantine and pitifully inadequate for managing this pandemic. At such a crossroad the constitution of an Education department has opened up new complications.

The NMC members are selected by strict criteria, but the head of the education department is not, thereby making the education system a corrupt, biased, and inefficient body. Ancient Hindus were great in education and Rig Veda is considered to be the earliest written literature. The way the ancient Hindus thought and taught wasvery interesting. May we look back to this treasure house of the ancient wisdom of the Hindus in their education system and apply some of the ideas in the modern-day teaching of Medical science, to improve the delivery of health care to the ill and needy.

\section{Review of literature}

The Rig Veda is undoubtedly the oldest holy book of the ancient Hindus. It contains many verses depicting prehistoric times. The oldest evidence of the HinduCivilizationdates back to approximately 6000 B.C. It is explained that the ancient Hindus coexisted with the Greeks, Persia, and Egypt. In his claim, Megasthenes, the envoy of the Alexander the Great, discovered a stone plate, which had 153 Indian Kings till Chandragupta, spanning over a period of 9000 years from today. If you consider the dates, it predates the old kingdom of Egypt and 2000 years before the great pyramid was built [1]. An extensive system existed in the ancient times for imparting education amongst the Hindus. Education was a compulsory part of life in both the male and females. The part was called Brahmacharjya. Few of the methods are being mentioned here, which should be relevant for the purpose of this work. These were namely-

A. Literary accomplishments. That included,

01. Reading, Reciting and speaking eloquently.

02. Lexicography and Versification.

03. Writing in cryptic hymns.

04. Filling up of the blanks in partially complete verses

05. Guessing hidden letters and materials held inside a clenched fist, to improve sixth sense or intuitive mind.

06. Use of secret languages or developing cryptic communications.

07. Learning languages in various forms.

08. Solving problematic riddles.

09. Solving oral puzzles.

10. Mime and mimicry.

B. Manual work and occupations.

01. Drawing.

01. A picture.

02. A Scenic representation or scenery.

02. Modeling.

01. Wood carving

02. Making Ornaments, flowers.

03. Flower arrangements.

The students were expected to follow a disciplined 
Life and utmost respect was expected of them for their teachers. Some of those rules can be enumerated here for the purpose of the suggestions for implementation in teaching modern medical science in India.

Rules of the conduct of the students towards the instructor -

01. Must have control over the body, speech, sense, and thought, the disciple should stand with folded hands and look towards the face of his teacher.

02. Always keep the right arm out of the garment, be decent, and keep the body well covered. The student must sit down facing the teacher and only sit when permitted to.

03. In the presence of the teacher, the student would always eat frugally, wear the simple and inexpensive dress and ornament. The students were expected to rise first in the morning and sleep last.

04. The student will not talk to his teacher from a reclining position and from the bed.

05. He should talk to his teacher standing up. The student will walk with teachers when the teacher is walking and would run if need be.

06. The student must always face his teacher and would follow him for instructions. He would lean towards the teacher to listen to his instructions. The Student must always take a lower position than the teacher

07. The student's bed or seat should always below. The students were supposed to sit decently in front of the teachers.

08. Naming the teacher, Telling Lies to the teacher, mimicking the teacher was prohibited.

09. A disciple should cover his ears or go away from situations where the teacher is defamed.

10. Students were expected to assist the teacher themselves. They were supposed to be away if they were upset or there was a woman present nearby. The students were expected to get down from the vehicles if they saw their teachers.

11. Students were not expected to speak anything unpleasant behind the back of their teachers [2].

Two factors in education are noted by those into Educators' education and Research:

\section{Internal and}

\section{External}

The first includes all the in-born Characters and capacities. This is the Genetic Characters or qualities by the birth of the child. These qualities were already there and could not be influenced or changed.The second is the environmental effects on the child. This includes his language, manners, customs, and beliefs, but also by the guidance that comes from the seniors, family members, and the surrounding community. This is probably akin to Phenotype. These external influences actually show the outside world the identity of the students. The early Hindu Educators looked into these facts very seriously. Much importance was given to the effect of the external factors in the shaping the future adult and hence the students were sent to the Teachers before the inborn qualities were eclipsed by the exposure to the surrounding environment. This was done for the development of the spiritual aspect of the individual. Spiritual development or improvement was considered of utmost importance in ancient Hindu education. The school environment was peaceful and without any conflicts. The Teachers themselves used to be the enactment of purity of souls, minds, and characters. This pure, disciplined life could stimulate the students towards learning and they did so quite splendidly. This unique style and place of Education was prevalent over 3000 years in the ancient Hindu system and was successful in maintaining the superiority of the style over other ways of teaching. This isactually the basis of the system of Residential Universities we see presently. The students lived with the teachers as one of his family. The Residential institutes were funded by at times, the kings and nobles or the students used to pay the Teachers from their side [3]. The ultimate aim of the ancient Hindu education system was to produce a person morally correct, spiritually inclined, socially responsible, respectable to tradition and holy spirits or gods, environmentally conscious, and family person. After the period of education, a person was capable enough to perform the five duties expected of them while in family life.

These were:

01. The learning and teaching of the Vedas,

02. Offering prayers to the forefathers

03. Offering prayers and worshiping the gods,

04. Offering food to birds, animals pets and nonpets alike and

05. Entertaining guests. 
The students thus were trained to become experts in the daily activities and were capable of maintaining a stable and moral life. As the Moral and spiritual aspects of life we're given more importance in the ancient Hindu civilization, the students were gently guided in the residential school towards that. The teachers themselves used to be the epitome of examples of the future life of the individual students once they are allowed to go out and start a family. In short, the ancient Hindu system guided the students to form good habits, of courteousness, of stable temperament in thoughtand of expression by works to various ideas of harmonious and virtuous conduct in life. During the adolescent period when the ideas and fantasies of sex and sexualities manifested, the Hindu system of education gave them training in self-control and self-sacrifice. The merit of the Hindu education system was that the students were stimulated to practice. The influence on the disciple was enhanced by the fact that the Hindu student and his teacher were bound not by any economic ties, but by those of friendship and affection. Hence the teacher exerted a far-reaching influence upon the disciple in molding his mind and character in a moral and spiritual way [3-4]. It is not easy to say when a boy or girl becomes a man or a woman. Most of these changes occur before the age of twenty, but some may not appear until ten or fifteen years later. Roughly speaking, infancy and childhood last about, ten to twelve years, adolescence or the transition period about ten to twelve years, vigorous maturity about 30-36 years, and old age or decadence, about twelve. Some powers and capacities mature and fail earlier and others later than at these periods. There are also great individual differences as to the age at which maturity is achieved, and at which the old age begins. As life becomes more complex, more specialized training is needed before a young man is prepared to make a living for himself. The age of entering upon business and professional life is therefore from five to ten years later than it was fifty years ago. Discipline in the Hindu education systemwas generally mild. Teachers were supposed to instruct the Students, which will be of benefit to him/her. Punishment will be vocal and mild to start with. Only when the conduct was severely wrong to them, the student will be punished with a split bamboo for the sound effect or a rope to hit the pupil on the fleshy parts. Never be the child hit on the face, stomach, and perineum with such contraptions. Pinching ears was considered ideal humiliation for minor offenses [5-6]. The great scholar Max Muller pondered. To quote him "How
Then were these ancient hymns and the Brahmanas, and it may be, the Sutras too, preserved? Entirely by memory, but by memory kept under the strictest discipline." It was indeed the discipline that was the center point of the whole education system in ancient India.I quote again from the great author as rephrasing the following lines will not have the same mesmerizing quality of the author, who put it all in such sweet lyrical words. The words beckon from the long past culture of education from the land of the Rishi and Sages. "As far back as we know anything of India, we find that the years which we spend at school and at university were spent by the Hindu students in learning, from the mouth of a teacher, their sacred literature. This was a sacred duty, the neglect of which entailed social degradation, and the minutest rules were laid down as to the mnemonic system that had to be followed. Before the invention of writing, there was no other way of preserving literature. Think of that half-naked Hindu Rishi, repeating under the sky the sacred hymns which have been handed down to them for three or four thousand years by oral tradition and memory. This was an example of learning by the ancient Hindus and it was very effective. It is said that if writing was not invented if printing was not invented if India was never occupied by England, that young Brahman and his Teacher, a Rishi, along withthe students, his countrymen, would probably be engaged just the same in learning and preaching by heart the simple prayers first sung on the banks of the ancient river Sarasvati and the other rivers of the Panjab by Vasishtha, Visvamitra and others."

The task of teaching could be understood by the fact that a student of Rig-Veda, if sharp and assiduous, would take about six to twelve years to learn the Dashagranthas, the ten books, which consist of

01. The hymns.

02. The prose treatise on sacrifices,

03. The Aranyaka, the forest-book.

04. The rules on domestic ceremonies.

The six treatises on siksha,

01. Pronunciation,

02. Jyotisha,

03. Astronomy,

04. Kalpa,

05. Ceremonial procedures, 
06. Vyakarana, (Grammar) etc.

A student studied and learned, under the attention of the teachers, in the teacher's home, called a Gurukul.Every day was a working or learning day. There were no-study holiday days too. It was a dedicated celibate time of six to twelve years of the studenthood. If one calculates the task, it would be something like this. There would be 360 days in a lunar year, and if you take an average eight years of the studenthood, available days for teaching would be 2880 days. From this 384 no-study holidaysto be deducted.That finally comes down to 2496 teaching days available to the team. TheGuru (Teacher) would teach the students everything without fail in the2496 days during the average eight years. The books, needed to be taught and learned, consisted of around 29,500 shlokas or Hymns or small poetries. The student, therefore, had to learn, understand, and commit to memory around twelve shlokas every day. Every shloka consisted of thirtytwo syllables. Such effective was the teaching methods in the ancient Hindu education system that all students would be proficient. Some might take a few years more, but all would learn and would be ready to teach if need be [6]. Similarly, the Ayurveda, which was a part of the Atharba Veda, was also taught in an equally effective way.

The Ayurvedic treating subjects comprised of eight branches:

01. Kayacikitsa(Internal medicine);

02. SalyaTantra (surgery);

03. Alakya tantra (ophthalmology and ENT);

04. Kaumarabrhtya(pediatrics, obstetrics, and gynecology);

05. Agada tantra (toxicology);

06. Rasayana(geriatrics and nutrition);

07. Vajikarana(sexology);

08. BhutaVidya (psychiatry and demonology).

The teachers were dedicated to the treating branches and were considered an expert in their fields. Students used to flock to the teachers for learning the subject, in which they were interested. No teachers, who were not involved in treating, were allowed to teach the treating subjects. The sanctity and purity were thus maintained during the ancient Hindu methods of Medicine. Because of the purity of the ancient system, the subject was gaining importance. Interested people from far and wide places used to come to learn the branches of
Medicine from the ancient Rishis. Scholars from Persia, Greece, Egypt, and the Middle East, which were ancient colonies of the Indian civilization, used to come to learn medicine as well as surgery from the great Teachers in India [7]. As per the legend goes, the father of surgery, Susruta and Atreya were theteachersof Jeevaka. Dhanwantary and Atreya were taught medicine by the lord Indra. Lord Indra was handed over the knowledge by the Lord Brahma himself. Verily the ancient Medicine of the Hindus was considered a sacred branch and was a part of the Fourth Veda, the Atharba Veda. It was justly named AyurVeda; means Life Science. The Vedas were extensive books, composed of verses. It was written down in a much later period. Before that students committed these to memory and passed on to the next generation. Atreya Samhita is said to have nearly 50,000 verses. A huge encyclopedia of medicine and was propagated so well that the students became even greater than their teachers, Jeevaka, as reported, operated on the King Bimbisara and Gautama Buddha. Charaka wrote Charaka Samhita, which is revered more than those of his teachers [5-8]. There are some works and ideas about the introduction of certain Ancient methods in making higher medical learning more efficient in India. The ideas from the Buddhist as well as the Islamic methods of teachings are also worth looking into. Improving the delivery of medical education will certainly improve the delivery of medical care in India and subsequently the world [9-10].

\section{Discussion}

The ancient Hindus had a written script from almost 6000 years from today. It was a treasure house of knowledge. Sanskrit is the mother language of all European Languages. People from the entire world, especially Persia, used to come to the ancient Hindus for learning and spread it to the world. There must have been something in the teaching methods in the ancient Hindus, which made them masters. People exposed to the ancient Hindu medicine are aware of Susruta Samhita, Atreya Samhita, and Charaka Samhita. Dhanwantary, the god of healing as per the faith of the ancient Hindu system of Medicine, was the teacher of the great Susruta, the Father of Surgery in Ancient India. He wrote the Susruta Samhita and described various operative procedures and Surgical Instruments, which are relevant till today. It is important to note that Ayurveda emphasizes that the individual as a whole must be examined in detail for one's disease and 
Not merely the disease or the ailment the patient is suffering from. The method of teaching was special. The teachers were called Rishis. A Rishi not only excelled in education and teaching but was a farmer, a Family man/ woman, and if necessarya warrior. The Rishis used to put great emphasis on purity of character. The students were eager to learn and used to come to the homes of their teachers for a part of their lives. They used to be initiated into the life of a Brahmacharya. The purity of thought, Rigorous daily activities, simple food, away from any greed or lust, and celibacy were considered of vital importance during the student period of Brahmacharya. Any student found wanting in these aspects would be turned back from the school. The lifestyle of the students was such that their mind will only be focused on learning. This period used to be anything from 6 years to 18 years when they would be certified to be fit to leave the school and will be allowed to get married and live a family life. Many of such trained students became great Rishis themselves. Many of them retired in the forests to lead a life of a sage. But students used to flock around and were ready to learn on any terms of those great Rishis. The question comes to the mind is what went wrong? The students joining medical college after grueling academic schedule, why do they fail to rise to the level of excellence expected of them?. Here a looking back on the ancient Hindu ways may give some insight.Surgery was considered the ultimate healing subject. It is also the first chapter of Ayur Veda. Susruta taught the students the supremacy of Surgery over other conjectural treatments. Anatomy was given immense importance and a novel way of Water digestion method was used for demonstrating and learning anatomy. The whole medicine was nicely compartmentalized and the Rishis, the teachers, experts in the particular branch would impart education to the students. Imparting practical hands-on teaching was given to the students. Both Surgical and Medicinal branches used to impart practical training.

\section{Conclusion}

It is high time that these ancient principles of the Hindu Educators be looked into and utilized to propagate knowledge in Medical education in India. With the introduction of some of the disciplines and methods like recitation, committing to memory of the mnemonics, and the basic emergency protocols with the help of the teachers from the non-treating branches, this can be attained. A properly educated
Treating doctor is an asset to society. By applying some methods of the ancient Hindu style of teaching as well as learning, the standard of teaching of the medical treating subjects can be made reliably efficient.

\section{Disclaimer}

All the views, thoughts and opinions expressed in the text belong solely to the author,and not necessarily to the Journal. The Journal does not endorse the views of the author published in the paper. The paper publisheddoes not intend to hurt religious sentiments of anyindividual, group, or community.

\section{Reference}

01. Muthu C. A Short Review of the History of Ancient Hindu Medicine. Proceedings of the Royal Society of Medicine. 1913 May;6;177-90. [Crossref]

02. Kirkpatrick EA. Fundamentals of Child Study- A Discussion of Instincts and Other Factors in Human Development, with Practical Applications. Macmillan. 1917.

[Crossref]

03. Kalam Chouhan. Education system in ancient India. Int JHist Res. 2016;6(2)1-4.

[Crossref]

04. Nogendra N. Mazumder with an introduction by $E$ E Biss. Ahistory of education in ancient In dia by Macmillan \& Co, Itd Calcutta.

[Crossref]

05. Buhler G. Manusmriti- The Laws of Manu, Translated with extracts from seven commentaries. Sacred Books of the East. $1886 ; 25$.

[Crossref]

06. Müller FM. Lectures on the origin and growth of religion as illustrated by the religions of Indiadelivered in the Chapter House, Westminster Abbey. Longmans, Green, and Company. 1878. [Crossref]

07. Seal B. The positive sciences of the ancient Hindus. Longmans, Green and Company. 1915. [Crossref]

08. Subbarayappa BV. The roots of ancient medicine- an historical outline. J Biosci. $2001 ; 26(2) 135-143$. Available at [Article] [Crossref] 
09. Ganguly N, Phukan Ray R. Infusing Teaching methods in the Medical Education System in India from the wisdom of the ancient Buddhist teaching ways, will improve the quality of the treating Doctors. WJPMR. 2019;5(11)55-59. [Crossref]
10. Ganguly N, Phukan Ray R. Methods of teaching in Islam and incorporating certain ideas into the teaching of the modern medical Science in India- Some thoughts and some observations. Int J Med Res Rev. 2019;7(6)568-73.

Available from: [Article] [Crossref] 